Environment Conservation Journal 16 (SE ) 251-258 , 2015

ISSN 0972-3099 (Print) 2278-5124 (Online)

Abstracted and Indexed

\title{
Qualitative Evaluation of Potential Impacts of Effluent of Genaveh Hospital Wastewater Treatment Plant on Soil and Plants
}

\author{
Abdoljalil Mohammadi, Esmaeil Kouhgardi and Tirdad Maghsoudloo
}

\author{
Received:20.08.2015
}

Revised:25.08.2015

Accepted: 30.09.2015

\begin{abstract}
Increasing population growth, improve living standards and industrial development are factors which increase water consumption and waste production. Therefore, the use of treated wastewater in agriculture to overcome the problems of water scarcity, particularly in areas with water shortages, is important. In this study in addition to assessing the performance analysis of Genaveh hospital wastewater treatment plant, The quality of the output of effluent of wastewater treatment plant for use in agriculture based on Ayers water quality guidelines were assessed and its potential adverse effects on soil and plants were evaluated. In this study within six months physical and chemical parameters such as pH, EC, calcium, magnesium, sodium, chloride, nitrate, bicarbonate, TDS and heavy metals (iron, manganese, nickel, cadmium, cobalt, lead and zinc) in the output effluent were determined according to standard methods. According to the obtained results, the use of hospital effluent Genaveh in agriculture in term of concentration of sodium in terms of SAR, bicarbonate, chloride, Adsorbed sodium absorption ratio encountered with low to moderate limitation of electrical conductivity. Severe limitations in terms of nitrate nitrogen and heavy metals concentrations in the range are determined. In general results of this study indicate that to reuse the Genaveh hospital effluent in agriculture continuous monitoring of the output of effluent of wastewater treatment plant to meet environmental standards is essential.
\end{abstract}

Keywords: effluent, wastewater treatment plant, Ayers and Westcot guideline, hospital, Genaveh.

\section{Introduction}

Increasing growth of population, improved living standards, industrial development and technology transfer are factors which increase water consumption and waste production in societies and environmental contamination; this caused problems which urge the investment on treatment and sanitary disposal (Zafarzadeh et al., 2013). Currently, decision-makers are concerned with application of effluent discharged from wastewater treatment plants in agriculture to compensate the lack of water resources and provide food security (Mahvi et al., 2009). However, these waters contain minerals such as salts, sodium, chlorine, bromine, microorganisms, and in some cases, heavy metals or other harmful organic and inorganic compounds (Commission on Goscience, 2003). It is noteworthy that successful utilization of sewage in agriculture requires the consideration of its effects on the environment, agricultural yields and human health; otherwise, it will cause serious damage to nature and human society (Feizi, 2001).

\section{Author's Address}

Environmental Department, Bushehr branch, Islamic Azad University, Bushehr, Iran.

E-mail: mohammadiabdoljalil@gmail.com
When using wastewater for irrigation, it is essential to consider the effects of inorganic and organic compounds existing in wastewater on the growth of plants and changes in the structure and chemical properties of soils (accumulation of nitrogen, phosphorus and heavy metals) followed by rises of toxins in the soil, plant and animal tissue and eventually human food chain as well as substances such as nitrate and toxic solutions leached from the soil into groundwater (Kalavarouziotis, 2008; Kiziloglu, 2008; Pales, 2009). Establishment of wastewater treatment plants alone cannot eliminate environmental concerns; instead, their performance needs to be evaluated consistently to meet environmental standards (Cirja et al., 2008). Therefore, potential advantages of treated effluents can be used by proper management in accordance with international physical, chemical and microbial standards. One of the most common guidelines in relation to physical and chemical parameters as well as heavy metals existing in irrigation waters is Ayers and Westcot guideline (Ayers and Westcot, 1985), as presented in Table 1 and 2. The Ayers and Westcot guideline is based on many studies conducted on factors such as percentage of 
leaching, changes on soil permeability changes due to EC, sodium absorption ratio (SAR), salinity tolerant plants, sodium, toxicity and other trace elements; therefore, it can be used to evaluate the quality of effluent used for agriculture (Danesh \&
Alizadeh, 2008). In the present research the quality of Genaveh hospital wastewater treatment plant effluent in terms of potential impact on soil and crops to extrapolate the quality parameters provided by Ayers and Westcot have been evaluated.

\begin{tabular}{|c|c|c|c|c|c|}
\hline \multicolumn{2}{|c|}{ Potential problems } & \multirow{3}{*}{$\begin{array}{l}\text { Unit } \\
\text { dS.m-1 }\end{array}$} & \multicolumn{3}{|c|}{ Safety limit } \\
\hline & & & Unlimited & $\begin{array}{l}\text { Low to } \\
\text { moderate }\end{array}$ & High \\
\hline \multirow[t]{2}{*}{ Salinity } & Electrical conductivity & & $>0.7$ & $3-0.7$ & $<3$ \\
\hline & Concentration of dissolved solids & mg.L-1 & $>450$ & $2000-450$ & $<2000$ \\
\hline \multirow[t]{5}{*}{ Permeability } & SAR: $0-3$ & & $0.7>$ & $0.2-0.7$ & $0.2<$ \\
\hline & SAR: $3-6$ & & $1.2>$ & $0.3-1.2$ & $0.3<$ \\
\hline & SAR: $6-12$ & & $1.9>$ & $0.5-1.9$ & $0.5<$ \\
\hline & SAR: 12-20 & & $2.9>$ & $1.3-2.9$ & $1.3<$ \\
\hline & SAR: $20-40$ & & $5>$ & $2.9-5.0$ & $2.9<$ \\
\hline \multirow{3}{*}{$\begin{array}{l}\text { Specific Ion } \\
\text { Toxicity }\end{array}$} & Sodium (Superficial irrigation) & SAR & $>3$ & $9-3$ & $<9$ \\
\hline & Chloride & meq.L-1 & $>4$ & $10-4$ & $<10$ \\
\hline & Boron & mg.L-1 & $>0.7$ & $3-0.7$ & $<3$ \\
\hline \multirow{3}{*}{$\begin{array}{l}\text { Other } \\
\text { Effects }\end{array}$} & Nitrogen $(\mathrm{NO} 3-\mathrm{N})$ & mg.L-1 & $>5$ & $30-5$ & $<30$ \\
\hline & Bicarbonate & meq.L-1 & $>1.5$ & $8.5-1.5$ & $<8.5$ \\
\hline & $\mathrm{pH}$ & - & \multicolumn{3}{|c|}{ Normal range $6.5-8.4$} \\
\hline
\end{tabular}

Table 1: Quality of irrigation water based on Ayers and Westcot guideline

\begin{tabular}{|l|l|l|l|l|l|}
\hline Parameter & Unit & Value & Parameter & Unit & value \\
\hline Aluminum & mg.L-1 & 5.0 & Iron & mg.L-1 & 5.0 \\
\hline Arsenic & mg.L-1 & 0.10 & Lithium & mg.L-1 & 2.50 \\
\hline Beryllium & mg.L-1 & 0.10 & Manganese & mg.L-1 & 0.20 \\
\hline Cadmium & mg.L-1 & 0.01 & Molybdenum & mg.L-1 & 0.01 \\
\hline Cobalt & mg.L-1 & 0.05 & Nickel & mg.L-1 & 0.20 \\
\hline Chromium & mg.L-1 & 0.10 & Lead & mg.L-1 & 5.0 \\
\hline Copper & mg.L-1 & 0.20 & Selenium & mg.L-1 & 0.02 \\
\hline Fluoride & mg.L-1 & 1.0 & Vanadium & mg.L-1 & 0.10 \\
\hline Zinc & mg.L-1 & 2.0 & Titanium & mg.L-1 & - \\
\hline
\end{tabular}

Table 2: maximum concentrations recommended for trace elements in irrigation water (Ayers and Westcot,1985)

\section{Studied Location}

Genaveh, one of the counties in north of the Bushehr Province, is located on the south of Iran at coordinates $50^{\circ} 8^{\prime}-50^{\circ} 53^{\prime} \mathrm{E} \quad 29^{\circ} 10^{\prime}-29^{\circ} 44^{\prime} \mathrm{N}$. The annual rainfall is $150 \mathrm{~mm}$, on average. The important hospital of Genaveh County is Amir AlMomenin Hospital with 92 beds. On average, the hospital consumes $59.58 \mathrm{~m} 3$ per day. This hospital is adjacent to the Shahid Choroomi Hospital; therefore, wastewater treatment plant of Amir AlMomenin Hospital treats the sewage discharged from Shahid Choroomi Hospital. Shahid Choroomi

Hospital consumes $16.9 \mathrm{~m} 3$ water per day. On average, these two hospitals convert $65 \%$ of water to sewage. As a result, the plant receives $49.85 \mathrm{~m} 3$ sewage per day.

\section{Materials and Methods}

In this study to assess the quality of Genaveh hospital wastewater treatment plant effluent a period of 6 months from July 2013 to December 2013 and with monthly intervals some samples were taken from the input sewage and output 252

Environment Conservation Journal 
effluent and physical and chemical parameters such as $\mathrm{pH}, \mathrm{TDS}$, electrical conductivity, calcium, magnesium, sodium, chloride, nitrate, bicarbonate, and heavy metals (iron, manganese, nickel, cadmium, cobalt, zinc, lead) were measured. All conditions for sampling and testing were in accordance with standard methods for examination of water and wastewater done (APHA, AWWA and WPCF, 2005). SAR and adj RNa were calculated by:

$$
\begin{aligned}
& S A R=\frac{N a(\mathrm{meq} / L)}{\sqrt{(C a+M g) / 2}(\mathrm{meq} / \mathrm{L})} \\
& \operatorname{adjR}_{\mathrm{Na}}=\frac{\mathrm{Na}}{\sqrt{\frac{C a_{x}+M g}{2}}}
\end{aligned}
$$

Spectrophotometer (HACH-DR 2800) was used to determine the concentration of sodium, chloride and nitrate ions. In addition, concentration of heavy metals was measured by atomic absorption spectrometry equipped with graphite furnace; $\mathrm{pH}$ was measured by digital $\mathrm{pH}$ meter $(\mathrm{HACH}$, Sension156), and electrical conductivity (EC) was measured by digital EC meter. Calcium and magnesium were measured by titration using EDTA. The concentration of bicarbonate was measured by titration using sulfuric acid (APHA, AWWA \& WPCF, 2005). For higher accuracy, parameters were tested in three iterations. Data analysis was performed by SPSS, version 22 .

\section{Results and Discussion}

Figures 1 to 8 show the changes in physical and chemical parameters in the wastewater treatment plant effluent during the study period. Table 3 indicates the mean, standard deviation, minimum and maximum levels of heavy metals in wastewater treatment plant effluent under the study during the study period.

\begin{tabular}{|l|l|l|l|l|}
\hline $\begin{array}{l}\text { Descriptive statistics } \\
\text { Parameters }\end{array}$ & Mean & Standard deviation & Minimum & Maximum \\
\hline Iron & 48.35 & 3.224 & 40.80 & 56.2 \\
\hline Cobalt & 8.92 & 1.495 & 6.50 & 11.5 \\
\hline Nickel & 5.96 & 0.968 & 4.30 & 7.8 \\
\hline zinc & 18.86 & 2.082 & 16.20 & 22.7 \\
\hline Cadmium & 0.15 & 0.022 & 0.12 & 0.2 \\
\hline Lead & 6.82 & 0.893 & 4.80 & 8.2 \\
\hline Manganese & 15.70 & 2.360 & 12.50 & 21 \\
\hline
\end{tabular}

Table 3: Descriptive statistics of trace metals in the effluent $(\mu \mathrm{g} / \mathrm{L})$

\section{Adjusted SAR (adjRNa)}

The amount of adjRNa in hospital effluent of Genaveh was 4.34 and EC was $2.22 \mathrm{ds} / \mathrm{m}$, on average. Figure 2 shows the trend of changes in SAR during the studied period. According to Ayers and Westcot guideline, the evaluation suggests that the wastewater treatment plant -effluent can be used to irrigate crops with no limitation on adj $\mathrm{RNa}$ and EC.

\section{Sodium}

In order to evaluate the risk of sodium ions in superficial irrigation of crops, sodium adsorption ratio or SAR is used (Rahmani \& Feizi, 2008). Destructive effects of sodium include decreased penetration, difficult germination, poor soil ventilation, and prevalence of root and plant diseases (Amin et al., 2010). The value of SAR was 7.20 for the wastewater treatment plant effluent. In Figure 2 the process of SAR index changes during the study period are shown.Quality assessment of wastewater based on Ayers and Westcot guidelines (Ayers and Westcot, 1985). suggest that the use of effluent for irrigation of agricultural crops in terms of toxicity level of sodium ions, encountered with low to moderate limitations.. Hassanlee and Javan through evaluating the efficiency of Marvdasht wastewater treatment plant showed that the use of the effluent of this wastewater treatment plant to irrigate crops in terms of SAR index faced low to moderate limitation (Hassanlee \& Javan, 2005). 
These finding are consistent with results of AlTurki in relation with evaluation of the quality of the wastewater treatment plant of Buraidah in Saudi Arabia for reuse in irrigation (Al-Turki, 2010).

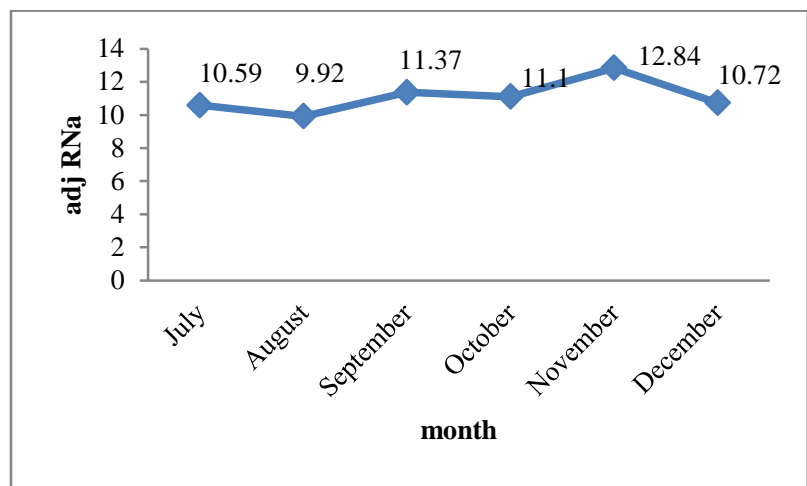

Figure 1: changes in adj RNa of the effluent

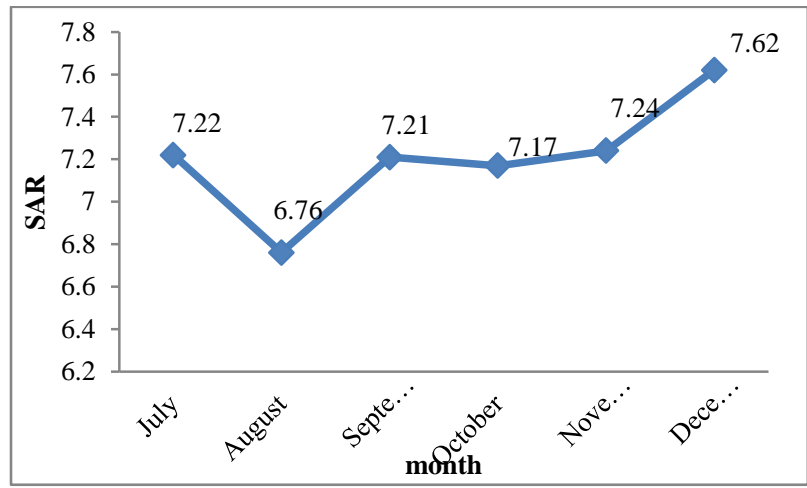

Figure 2: Changes in SAR of the effluent

\section{Chloride}

Chloride ion plays an important role in creating toxicity of plants and crops (Ayers \& westcot, 1985). Chloride ion isn't absorb in the soil particles level but with moisture transmitted to soil and after absorption through root, such as sodium accumulates in the leaves. Tree plants perennial plants are sensitive to low concentrations of chloride, while most of one- year plants aren't sensitive (Pescod, 1992). The process of Chloride concentrations change in effluent of wastewater treatment plant house under the study is shown in Figure 3 and the average amount of chloride ion in the effluent of under study wastewater treatment plant is $6.43 \mathrm{mEq}$ per liter. Therefore, the use of wastewater treatment plant wastewater for irrigating resistant plants such as alfalfa, wheat, barley, beets and mango is suitable. Research results Sabzevari and et al in relation with examine the quality of wastewater of wastewater treatment plant of Atieh sazan hospital in Hamadan suggests that the concentration of chloride in the wastewater treatment plant effluent for irrigating crops has low to moderate limitations (Sabzevari et al., 2005). The study result of Al-Khashman in relation with chemical assessment of sewage of Ma'an wastewater treatment plant in Jordan suggests that the use of the wastewater of mentioned wastewater treatment plant in terms of chloride ion has no restrictions (Al-Khashman, 2009).

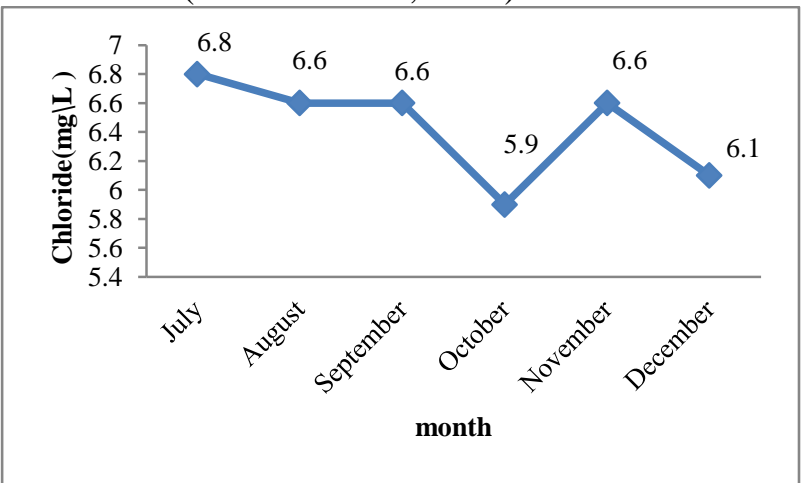

Figure 3: Changes in chloride of the effluent

\section{Nitrate}

Nitrate is one of the forms of nitrogen that depending on the refining process can be found in sewage effluent (Duncan et al., 2008). Nitrate nitrogen due to negatively charged is not removed through ion exchange with soil particles. If nitrates are not absorbed into the plant and microbes are not absorb it, directly goes into the underground aquifers and would be risky. Increasing the concentration of minerals, especially nitrogen, significantly affects the plant growth function and crops yield (Levy et al., 2011). Changing process in nitrate concentrations in effluent of under study wastewater treatment plant is shown in figure (4). Average of nitrate concentration in Genaveh AmirAL-momenin hospital wastewater treatment plant effluent is $32.14 \mathrm{mg} / \mathrm{L}$ which suggest that that the use of effluent for irrigation of agricultural crops in terms of toxicity of nitrate ions associated with severe restrictions. High levels of nitrate in the output effluent indicates that poor denitrification in refinement process of hospital that are related to hydraulic organic load applied to wastewater treatment plant lack or imbalance of return sludge from secondary sedimentation tank, is inappropriate amount of food for microorganism (F / M) (Mahvi 254

Environment Conservation Journal 
et al., 2009). Considering the criteria for recommended value in Ayers and Westcot guidelines, effluent the quality of wastewater treatment plant is not assessed desirably in terms of nitrate concentrations for irrigating crops. The result of analysis conducted by Akponikpe and et al in relation with the reuse of Domestic wastewater suggest that use of effluent of wastewater treatment plant in terms of nitrate has low to moderate limitations (Akponikpe et al., 2011). Also the study result of AL-Jaboobi and et al in relation with Effluent quality Sana'a in Yemen showed that nitrate concentrations in the wastewater treatment plant effluent for irrigating crops has low to moderate limitations (AL-Jaboobi et al., 2013).

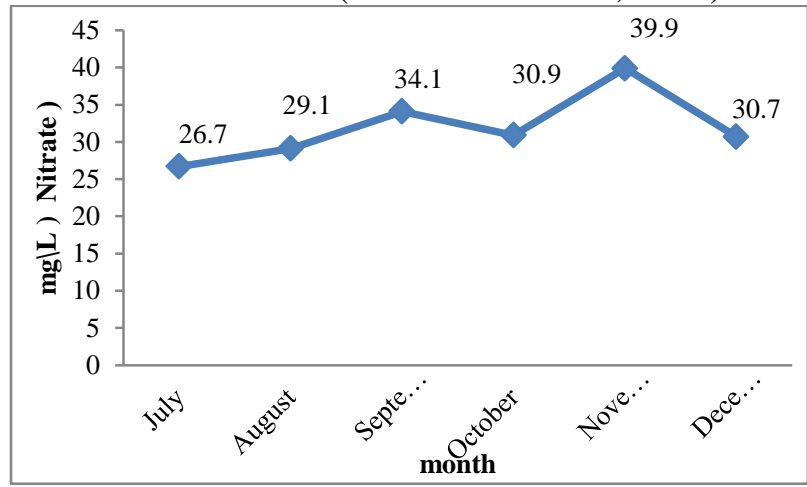

Figure 4: Changes in nitrate of the effluent

\section{Bicarbonate}

Bicarbonate, as one of the alkalinity agents, increases the potential soil degradation by precipitating calcium and magnesium ions (Ayers \& Westcot, 1985). In Figure 5, the bicarbonate changes during the study period are shown. The analysis results indicate that the average amount of bicarbonate in the wastewater treatment plant effluent is $203.30 \mathrm{mg} / \mathrm{L}$. comparing the obtained result with proposed criteria in Ayers and Westcot guidelines suggest the fact that bicarbonate concentration in the wastewater of wastewater treatment plant under the study is assessed desirably. The result of analyzes performed by Rahmani and Feizi(2008). in relation to the quality of wastewater treatment plant effluent of north of Isfahan suggest that use of wastewater of this wastewater treatment plant in agriculture in terms of bicarbonate concentration, faces low to moderate limitations. Also these findings are consisten with study result of Mouhanni and et al (Mouhanni et al., 2011).

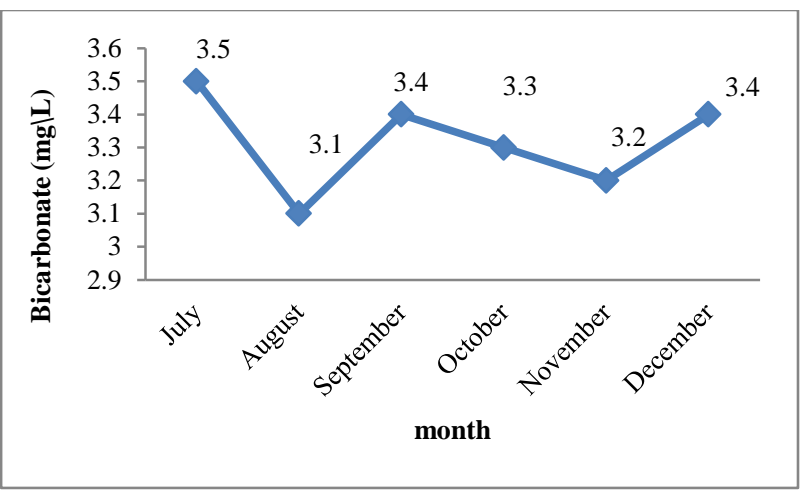

Figure 5: Changes in Bicarbonate of the effluent

\section{pH}

is one of the important effective parameter in biological process of refining the wastewater is $\mathrm{pH}$ and its changes. Generally favorable $\mathrm{pH}$ for the growth and activity of bacteria is in range of 6.5-8.5 and the activity of most of effective bacteria in reefing the wastewater is interrupted or stopped at $\mathrm{pH}$ greater than 9.5 (Amouei et al., 2010). It is a parameter influencing the relative solubility of nutrients and heavy metals that can affect plant growth and its performance (Ayers \& Westcot, 1985). The mean $\mathrm{pH}$ of the effluent of under study wastewater treatment plant is 6.92 during the study which is in normal range and will not adversely affect the irrigated soil and plants. PH changes in output effluent of refinery are shown in figure6. The study result of Massoudinejad and et al in relation with examining the quality of effluent of Zamyad factory suggest that the $\mathrm{pH}$ is in the standard range (Massoudinejad et al., 2006). Nazemi and et al evaluated the performance of Imam Hossein hospital wastewater treatment plant in Shahrood; they concluded that the $\mathrm{pH}$ of effluent treatment plant has no limitation for irrigating crops (Nazemi et al., 2009).

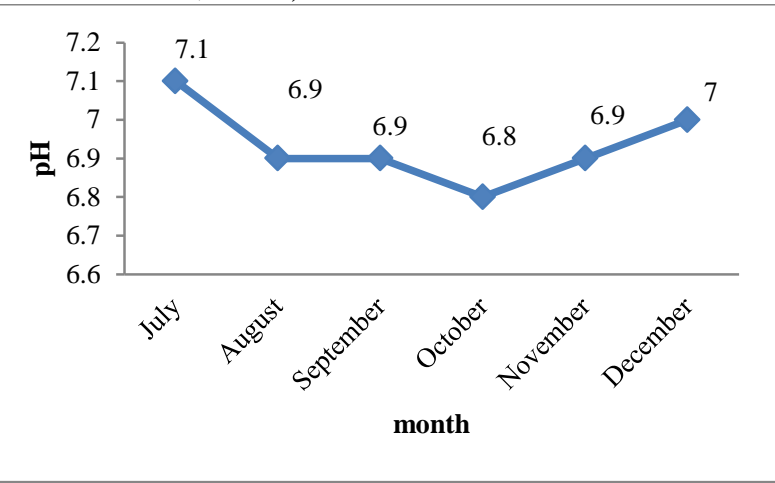

Figure 6: Changes in pH of the effluent 


\section{TDS}

Average TDS in the effluent under study wastewater treatment plant is $1683.04 \mathrm{mg} / \mathrm{L}$.

The process of TDS changes in the effluent of under study wastewater treatment plant is shown in figure 8. Comparing the obtained results with presented criteria in Ayers and Westcot guidelines suggest that TDS concentration in effluent of under study wastewater treatment plant has low to moderate limitations. The result of conducted research by Naseri and et al about assessing the reuse of Ardebil wastewater treatment plant suggest that TDS levels in effluent of wastewater treatment plant low to moderate limitations for irrigating crops (Nasseri et al., 2008). Also this finding is consistent with the result of Sabzevari and et al (Sabzevari et al., 2005).

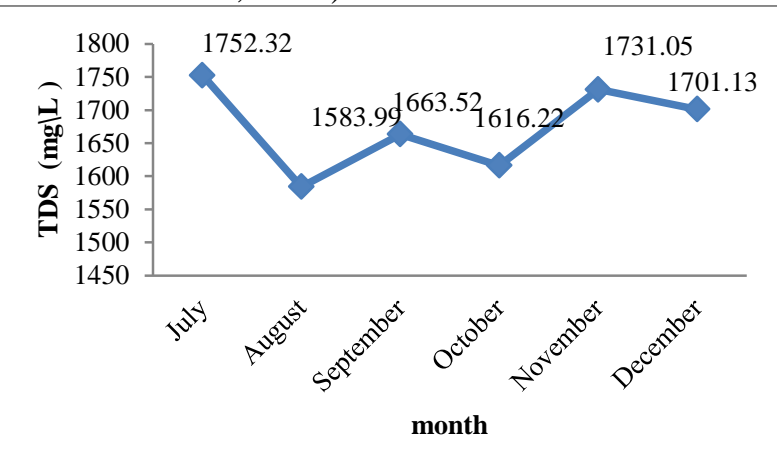

Figure 7: Changes in TDS of the effluent

\section{EC}

The electrical conductivity is directly related to the total anions and cations (Hassan Aghla et al., 2002). The EC changes in effluent of under study wastewater treatment plant are shown in diagram 8 . Average EC of effluent of under study wastewater treatment plant during the study was $2.23 \mathrm{ds} / \mathrm{m}$. According to the classification criteria of irrigation of Ayers and Westcot in terms of EC, the use of effluent of under study wastewater treatment plant is associated with low to moderate limitations. The study result of Massoudinejad and et al about investigating the reuse of effluent of Zamyad factory for irrigation suggest that applying the effluent of mentioned wastewater treatment plant in terms of EC has low to moderate limitations moderate (Massoudinejad et al., 2006 Based on the previous analyses, it can be concluded that the effluent used for irrigation of some crops can reduce the agricultural products in absence of salinity management methods. Due to the high salinity of the effluent, irrigation will be followed by $10 \%$ reduction in yields of corn, potatoes, turnips, clover, grapefruit, oranges, almonds and plums and $25 \%$ reduction in yields of more sensitive plants such as beans, carrots and apricots (Ayers \& Westcot, 1985; Mass, 1984).

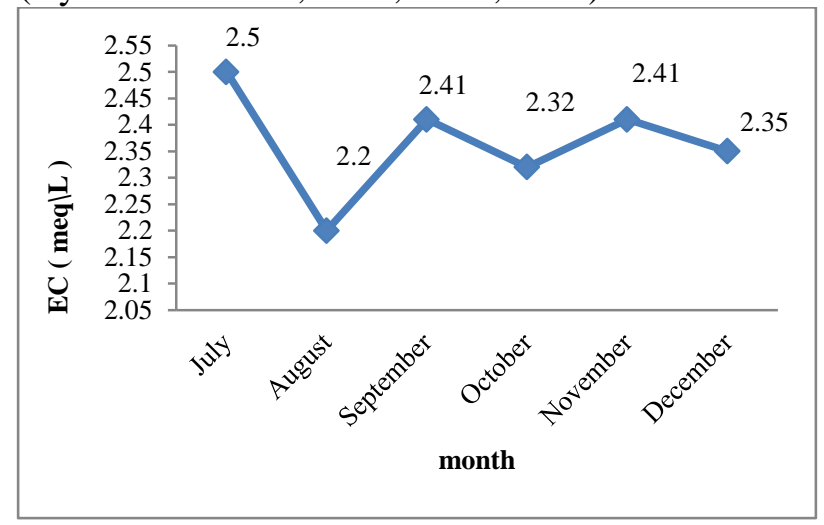

Figure 8: Changes in EC of the effluent

\section{Heavy Metals}

Long-term use of wastewater for irrigation often leads to the increased levels of heavy metals (Larcheveque et al., 2006). When the capacity of the soil to hold heavy metals (due to the increased level of heavy metals in the soil) decreases, heavy metals are released into the groundwater or in the form of solutions usable for plant absorption (Sharma et al., 2007). High concentrations of heavy metals in plants can influence the transfer and balance of essential elements through competitive adsorption (Schat \& Ten Bookum, 1992). Table 3 lists the mean, standard deviation, maximum and minimum concentrations of heavy metals (iron, manganese, nickel, cadmium, cobalt, lead and zinc) in Genaveh hospital wastewater treatment plant effluent. Comparing the measured values and maximum allowable values recommended in Ayers and Westcot guideline, it can be concluded that the concentration of heavy metals in wastewater treatment plant effluent is within the determined range, which is consistent with studies in Mexico city (Mireles et al., 2004) and in Turkey (Alaton et al., 2007). It is vital to consider the long-term effects of heavy metals in soil and plants tissues that need to be monitored periodically based on a proper management of effluent quality, soil and irrigated crops. 


\section{Conclusion}

According to the results obtained in this study, the performance of Genaveh Hospital wastewater treatment plant - effluent in removing all parameters except TDS and nitrate is suitable. In terms of concentration of parameters EC, sodium, chloride, bicarbonate and adj $\mathrm{RNa}$ index for agricultural use is with low to moderate limitation and in relation to the concentration of nitrate ion has a severe limitation. Therefore, it can be concluded that in order to avoid adverse effects of prolonged use of Genaveh hospital wastewater treatment plant effluent on irrigated soil and crops requires continuous monitoring of effluence and fixing the flaws in ventilation system and the return

\section{References}

Akponikpè P B I, Wima K, Yacouba H, Mermoud A 2011. Reuse of domestic wastewater treated in macrophyte ponds to irrigate tomato and eggplant in semi-arid West-Africa: Benefits and risks. Agr. Water Manag., 98: 834-840.

Alaton IA, Tanik A, Ovez S, Iskender G M, Orhan D 2007. Reuse potential of urban wastewater treatment plant effluent in Turkey:a case study on selected plants. Desalination, 215: 189-198.

Al-Khashman O A 2009. Chemical evaluation of Ma' an sewage effluents and its reuse in irrigation pur poses. Water Resour. Manage. 23(6): 1041-1053.

AL-Turki 2010. Assessment of Effluent Quality of tertiary wastewater treatment plant at Buraidah city and its reuse in irrigation. J. Appl. Sci., 10(16): 1723-1731.

AL- Jaboobi M, Bouksaim M, Tijane M, EL-Ariqi S 2013. Agricultural Quality Evalution of wastewater, used in Yemen vegetables production. Meddle-East J. Sci. Res., 16(5): 667-677.

Amin MM, Hashemi H, Bina B, Movahhedian Attar H, Farrokhzadeh H, Ghasemian M 2010. Pilot- scale studies of combined clarification, filtration, and ultraviolet radiation systems for disinfection of secondary municipal wastewater effluent. Desalination; 260: 70-8.

Amouei A, Asgharnia H A, Goodarzi J, Salehi A 2010. Characteristics of wastewater in the hospital of babol medical university.

APHA, AWWA, WPCF 2005. Standard methods for the examination of water and wastewater, 21th Edition. APHA, Washington D.C . sludge flow. In that case, the effluent can be used to grow plants resistant to salinity and resistant to moderate concentrations of other parameters. Since the use of refined effluent reduces the cost of water needed for irrigation in farms, in the present condition of dehydration, we can through optimize the management of wastewater for irrigation crops in area and for irrigation of green space of hospital can be used.

\section{Acknowledgments}

The outhors of the paper are thankful of helping of hospital manager and effluent refinery operator.

Ayers R S, Westcot D W 1985. Water quality for agriculture. FAO Irrigation and Drainage Paper, 29: 17.

Cirja M, Ivashechkin P, Schäffer A, Corvini PF 2008. Factors affecting the removal of organic micropollutants from wastewater in conventional treatment plants (CTP) and membrane bioreactors (MBR). Rev. Environ. Sci. BioTech., 7(1): 61-78.

Commission on Goscience, Environment and reasources, 2003. Use of Reclamed Water and sludge in food crop production, the National Academie press.

Danesh Sh, Alizadeh A 2008. Application of effluent in agriculture, opportunities and challenges. The first national conference on role of effluent and reuse water resources management, Mashhad.

Duncan R R, Carrow R N, Huck M T 2008. Turfgrass and Landscape Irrigation Water Quality: Assessment and Management. CRC Press., USA.

Feizi M 2001. Effect of Treated Wastewater on Accumulation of Heavy Metals in Plants and Soil. International Workshop on Wastewater Reuse Management. ICID-CIID. Seoul, Korea. pp. 137-146.

Hassan Aghla A, Liaghat A, Mirabzadeh M 2002. Changes of soil organic matter as a result of domestic sewage and assimilative water, Journal of Water and Wastewater, 42: $2-11$.

Hassanlee AM, Javan M 2005. Evaluation of municipal effluent and its application in landscape irrigation, Case Study (marvdasht wastewater treatment plant). Ecology 38: 23-30. 


\section{Mohammadi et al}

Kalavarouziotis I 2008. "Effect of municipal reclaimed wastewater on the macro-and micro-elements status of soil and of Brassica oleracea var.Ita lica(Brocoli), and B.oleracea var Gemmifera(Brussels sporouts)",Agricultural water management, No.95, Greece.

Kiziloglu F M 2008. "Effects of untreated and treated wastewater irrigation on some chemical properties of cauli flower (Brussica olerecea L.var.botrytis)and red cubbage(Brassica olerecea L.var.rubar)grown on calcareous soil in Turkey" Agricultural water management, No.95, Turkey.

Larcheveque M, Ballini C, Korboulewsky N, Montes N, 2006. The use of compost in afforestation of Mediterranean areas: Effects on soils properties and yong tree seedlings. Science of the total Environment, 369: 220-230.

Levy G J, Fine P, Bar- Tal A 2011. Treated wastewater reuse in agriculture: use and impacts on the soil environment and crops John Wiley and Sons Inc., New York, USA.

Mahvi A, Rajabzadeh A, Yosefi N, Hosseini H, Ahmadian M 2009. Survey wastewater Treatment condition and effluent Quality of Kerman province hospitals. World Appl. Sci. J., 7(12): 1521-1525.

Mass E V 1984. Salt Tolerance in Plants. In: B.R. Christie, (Ed.), The Handbook of Plant Science in Agriculture. CRC Press, USA.

Massoudinejad M R, Manshouri M, Yazdanbakhsh A R 2006. Study on the reuse of Zamyad Factory wastewater treatment plants effluent in irrigation. Iran. J. Health. Sci.Eng., 3(4): 285-288.

Mireles A, Soils C, Andrade E, Lagunas-solar M, Pina, C, Flocchini R G 2004. Heavy metal accumulation in plants and soil irrigated with wastewater from Mexico City. Nucl. Lns. Meth. Phys., B, pp. 187-190 .

Mouhanni H, Bendou A, Er-Raki S 2011. Disinfection of Treated wastewater and its reuse in the irrigation of golf Grass. The case of Plant M'zar Agadir-Moroco. J. water, 3: $1128-1138$.

Nasseri S, Sadeghi T, Vaezi F, Naddafi K, 2008. Evaluation of possible options for reuse of Ardebil wastewater treatment plant effluent . Iran. J. Environ. Health. Sci. 5(4): 297-304.
Nazemi S, Abbasi A, Nourian J, Sohrabi M B, Khosravi A 2009. Investigating the efficacy Imam Hossein hospital wastewater treatment plant. J. Know. Health, Tehran University of Medical Sciences.

Oran G, Gillerman L, Bick A, Manaor Y, Buriakovsky N, Hagin J 2007. Advanced low quality waters treatment for unrestricted use purposes: Imminent challenges. Desalination, 213: 189-198.

Pales A M 2009. "Irrigation of olive groves in southen Italy with treated municipal wastewater:Effect on microbiological quality of soil and fruits", Agriculture,Ecostystems and Environmental, NO.129, Italy.

Pescod M B 1992. Wastewater treatment and use in agriculture. FAO, Irrigation and Drainage Paper, 47: 118.

Rahmani H, Feizi R M 2008. Investigating the quality of Effluent of north of Isfahan. (2002-2004) and its evaluation for use in agriculture or in the environment, the Third National Congress of recycling and the use of renewable organic resources in agriculture, Isfahan.

Sabzevari A, Binavapour M, Mohamadtaheri A 2005. The survey of function of wastewater treatment in Hamedan Atieh- Sazan hospital and possibility of wastewater reuse for irrigation. Proceeding of $8^{\text {th }}$ University of Medical Sciences, pp. 1245- 1253.

Schat H, Ten Bookum W M 1992. Metal specificity of metal tolerance syndromes in higher plants. In: Proter, J.A., Baker, J.M., Reeves, R.D.(Eds.), The Ecology of ultramafic(Serpentine) Oils, Intercept Andover, M.A, pp:337-352.

Sharma R K, Agrowal M, Marshall F 2007. Heavy metal contamination of soil and vegetables in suburban areas of Varanasi, India. Ecotoxcology Env. Saf., 66(2): 258-266.

Zafarzadeh A, Rezayee A, Aghahosseini F, Charmsaz S 2013. Evaluating the performance of Agh Ghala industrial town wastewater treatment plant in nitrogen compound removal, phosphorous, and chemical oxygen demand (COD) and compare it with the effluent standard. J. Heal. Sys. Res., 8 (7): 1197-1205.-32. 